\title{
Study on Using Fly Ash for Fly Ash - Soil Piles in Reinforcing Soft Ground
}

\author{
Tuan Anh Nguyen ${ }^{1, *}$, Dat Thanh Nguyen², Tung Thanh Pham $^{3}$, Linh Truong Chau ${ }^{3}$ \\ ${ }^{1}$ Transportation Engineering Faculty, Ho Chi Minh City University Of Transport, No 2. Vo Oanh St., Ward 25, Binh Thanh Dist., \\ Ho Chi Minh City, Vietnam \\ ${ }^{2}$ Civil Engineering Faculty, Ho Chi Minh City University of Transport, No 2. Vo Oanh St., Ward 25, Binh Thanh Dist., \\ Ho Chi Minh City, Vietnam \\ ${ }^{3}$ Bridge and Road Construction Engineering, University of Science and Technology, The University of Da Nang, No. 54 Nguyen \\ Luong Bang St., Khanh Hoa Bac Ward, Lien Chieu Dist., Da Nang City, Vietnam
}

Received August 27, 2020; Revised September 28, 2020; Accepted October 30, 2020

\section{Cite This Paper in the following Citation Styles}

(a): [1] Tuan Anh Nguyen, Dat Thanh Nguyen, Tung Thanh Pham, Linh Truong Chau, "Study on Using Fly Ash for Fly Ash - Soil Piles in Reinforcing Soft Ground," Civil Engineering and Architecture, Vol. 8, No. 5, pp. 1074 - 1085, 2020. DOI: 10.13189/cea.2020.080534.

(b): Tuan Anh Nguyen, Dat Thanh Nguyen, Tung Thanh Pham, Linh Truong Chau (2020). Study on Using Fly Ash for Fly Ash - Soil Piles in Reinforcing Soft Ground. Civil Engineering and Architecture, 8(5), 1074 - 1085. DOI: 10.13189/cea.2020.080534.

Copyright $\bigcirc 2020$ by authors, all rights reserved. Authors agree that this article remains permanently open access under the terms of the Creative Commons Attribution License 4.0 International License

\begin{abstract}
Currently, the construction technology on soft ground reinforcement is very developed, including the technology of constructing soil-cement piles for soft soil reinforcement which is technically and economically effective and widely used. Another technology is using fly ash waste from thermal power plants to make fly ash- soil piles for soft ground reinforcement, which not only takes advantage of local materials but also reduces environmental pollution from operating thermal power plants. This paper introduces some research results on fly ash content and pile diameter when reinforcing soft ground. The authors modeled the calculation diagram of the soft ground reinforcement under the roadbed with the case of the hypothetical pile diameter $\mathrm{D}=40 \mathrm{~cm} ; 50 \mathrm{~cm} ; 60 \mathrm{~cm}$ corresponding to the content of fly ash $35 \%, 40 \%, 45 \%$, the pile length $\mathrm{L}=8 \mathrm{~m}$ to handle all soft ground layers. The results show that when the pile length $\mathrm{L}=8 \mathrm{~m}$, pile diameter $\mathrm{D}=60 \mathrm{~cm}$ corresponding to the fly ash content of $45 \%$, the stability coefficient of $K=1.992$ is larger than the allowable stability coefficient $[\mathrm{K}]=1.4$. In this case, the largest settlement strain $\mathrm{S}=0.17 \mathrm{~m}$, meeting permissible settlement strain of the ground $[\mathrm{S}]=0.3 \mathrm{~m}$. These results provide basement for the design, construction and operation management units to propose solutions to maximize the working ability of the materials, enhance the stability of the roadbed during exploitation.
\end{abstract}

Keywords Fly Ash-Soil Pile, Soft Ground, Reinforce Soft Ground, Roadbed Treatment, Physical Model, Numerical Model

\section{Introduction}

Currently, the construction technology of soft ground reinforcement is very developed, including the technology of constructing soil-cement piles for soft soil reinforcement which is technically and economically effective and widely used [1, 4, 26]. Fly ash waste (blast furnace ash) from thermal power plants can be used to produce fly ash-soil piles instead of soil-cement piles to reinforce soft ground. Therefore, studying on fly ash content and fly ash- soil pile diameter when reinforcing is very necessary and practical. $[3,5,27]$

According to the World of Coal Ash Conference (WOCA), $42.1 \%$ of fly ash is reused in the US, $90.9 \%$ in Europe, $96.4 \%$ in Japan, $67.1 \%$ in China, $13.8 \%$ in India, and $66.5 \%$ in other Asian countries, etc. [14].

In Europe, fly ash from thermal power industry is used as an additive in concrete mixes (29.5\%), raw materials for Portland cement production (26.9\%), and materials for roads construction and leveling (19\%), etc. [14]. 
In 2013, Japan recorded that 12.5 million tons of ash and slag were discharged. In which, the majority of ash and slag $(65.6 \%)$ were used for cement production, $5.6 \%$ used as leveling materials, and $4 \%$ used as reinforcement materials. China generated 440 million tons of ash, of which about $67 \%$ was reused. In India, the amount of fly ash discharged was 165 million tons, of which about $62.5 \%$ was reused. India used $41.2 \%$ of the fly ash as raw materials for cement production, $11.83 \%$ of waste for leveling, $6 \%$ in road construction and the rest was used as an additive to concrete, unburnt brick, ... [17].

Davidovits (1988) [6] studied that an alkaline activated fly ash mixture could harden within a few hours at normal temperature (about $30^{\circ} \mathrm{C}$ ), within several minutes when heated to $85^{\circ} \mathrm{C}$ and within seconds if subjected to microwaves. The compressive strength of this material will increase over time up to about 28 days, being similar to that of using Portland cement. Compressive strength can be $20 \mathrm{MPa}$ after four hours at $20^{\circ} \mathrm{C}$, while compressive strength after 28 days is in the range of $70-100 \mathrm{MPa}$.

Davidovits $[7,8]$ published a study on the ratios of molecules that make up fly ash cement material to obtain the products of high strength durability: the $\mathrm{M}_{2} \mathrm{O} / \mathrm{SiO}_{2}$ ratio is $0.2-0.48$; the ratio of $\mathrm{SiO}_{2} / \mathrm{Al}_{2} \mathrm{O}_{3}$ is 3.3-4.5; the water $/ \mathrm{M}_{2} \mathrm{O}$ ratio is $10-25$; the ratio of $\mathrm{M} 2 \mathrm{O} / \mathrm{Al}_{2} \mathrm{O}$ is $0.8-1.6$ (where $\mathrm{M}$ is the alkali metal).

Balo [2] conducted experimental studies of the mechanical and thermal conductivity of the materials created by mixing wasted fly ash, clay, epoxide palm oil and renewable materials. These studies show that the higher ratio of both fly ash and epoxide palm oil, the lower the coefficient of thermal conductivity, weight, and tensile - compressive strength of the experimental samples.

Lin Wuu [11,12] conducted a 1:1 scale experiment and numerical analysis on a high-speed rail substrate to evaluate the effectiveness of the piles underneath this ground which is made of gravel, fly ash and cement. The research results show that this pile works effectively and is suitable for completely decomposed granite soil.

$\mathrm{Na} \mathrm{Li}$ et al. [13] studied consolidation properties of coastal cement soil when adding appropriate amount of fly ash. The analysis results show that, when the cement content is $20 \%$, the fly ash content is $0 \%, 5 \%, 10 \%, 20 \%$, $30 \%$ respectively, and water content is $80 \%$, the ability to withstand compression of this material increases significantly.

Haibin Wei $[16,17]$ studied the solution of treating fly ash and oil shale ash by combining with mud clay. When applying this solution, the elastic modulus and stress state of the soil are significantly affected, leading to destruction of the initial structure and increase soil porosity.

Wang [15] conducted several studies on the swelling and stress properties of 16 types of mixtures made of cement, fly ash and lime. These studies show that the type of adhesive and the adhesive content have a great influence on the strain modulus, compressive strength, destructive strain and destructive mode, shape and position of stress curves.
Kuan [10], Xiao [18] studied the application of fly ash as an additive in soil improvement of construction works. When soft coastal clay is mixed with fly ash, the strength is significantly improved, the plasticity index and the compressive index decrease by $69 \%$ and $23 \%$ respectively.

This paper analyzes the performance of fly ash-soil piles at different diameters and different fly ash content in order to propose the most reasonable solution for soft ground treatment and reinforcement with fly ash-soil piles.

\section{Materials and Methods}

\subsection{Physical-mechanical Criteria of Fly Ash-Soil Pile}

\subsubsection{Physical-Mechanical criteria of fly ash}

To determine the physical and mechanical properties of fly ash, 2.5 tons of fly ash samples were taken. Random samples were taken uncontinously from the silo storage of Duyen Hai thermal power plant. After that, the authors selected 3 random sample groups to experiment with mechanical - physical - chemical parameters of fly ash.

The experimental results were analyzed at Quatest 2 laboratory by the method of infrared spectroscopy analysis. Two control samples were carried out at the laboratory of Road Technical Centre No. 3 by chemical and calcination methods. The average results are shown in Table 1.

According to TCVN 10302:2014: Base ash is ash with $\mathrm{CaO}$ content greater than $10 \%$, symbol: $\mathrm{C}$

Table 1. Fly ash test results

\begin{tabular}{|c|c|c|c|c|}
\hline No & Test criteria & $\begin{array}{c}\text { Test } \\
\text { method }\end{array}$ & Unit & Result \\
\hline 1 & Humidity & {$[22]$} & $\%$ & 0.26 \\
\hline 2 & Porous mass density & & $\mathrm{kN} / \mathrm{m}^{3}$ & 9.4 \\
\hline 3 & Density & {$[23]$} & $\mathrm{kN} / \mathrm{m}^{3}$ & 22.1 \\
\hline 4 & $\begin{array}{c}\text { Fineness (percentage of } \\
\text { passing } 0.08 \mathrm{~mm} \text { sieve) }\end{array}$ & {$[23]$} & $\%$ & 2.1 \\
\hline 5 & Loss after burning & {$[24]$} & $\%$ & 8.27 \\
\hline 6 & Content of $\mathrm{SiO}_{2}$ & {$[24]$} & $\%$ & 81.6 \\
\hline 7 & Content of $\mathrm{Fe}_{2} \mathrm{O}_{3}$ & {$[24]$} & $\%$ & 81.6 \\
\hline 8 & Content of $\mathrm{Al}_{2} \mathrm{O}_{3}$ & {$[24]$} & $\%$ & 81.6 \\
\hline 9 & Content of $\mathrm{SO}_{3}$ & {$[25]$} & $\%$ & 0.49 \\
\hline 10 & Content of $\mathrm{CaO}$ & {$[25]$} & $\%$ & 12 \\
\hline
\end{tabular}

\subsubsection{Physical-mechanical criteria of soft ground}

The technical criteria of the soil layers are determined according to the Report on the results of engineering geological survey of the new urban area located in the east of Mau Than street, Tra Vinh city, Vietnam.

From the current ground to the survey depth (HK1:20m, HK2: 40m), there are 06 soil layers. The distribution depth of each layer in the boreholes is shown in Table 2. 
Table 2. Technical properties of soil layers in boreholes

\begin{tabular}{|c|c|c|c|}
\hline \multirow{2}{*}{ Layer } & \multirow{2}{*}{ Soil name } & \multicolumn{2}{|c|}{ Thickness (m) } \\
\cline { 3 - 4 } & HK1 & HK2 \\
\hline 1 & Small sand, poor texture & 1.4 & 1.8 \\
\hline 2 & $\begin{array}{c}\text { Mud clay mixed with sand - } \\
\text { melted state }\end{array}$ & 1.1 & 6.8 \\
\hline 3 & Small sand, poor texture & 2.9 & 2.8 \\
\hline 4 & $\begin{array}{c}\text { Mud clay mixed with sand - } \\
\text { melted state }\end{array}$ & 8.6 & 20.8 \\
\hline 5 & Mixed clay, melted state & - & 1.4 \\
\hline 6 & $\begin{array}{c}\text { Clay, elastic hard to semi-hard } \\
\text { state }\end{array}$ & - & 6.4 \\
\hline
\end{tabular}

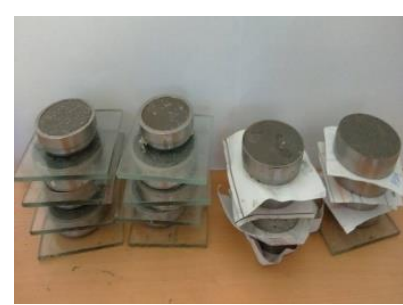

a)

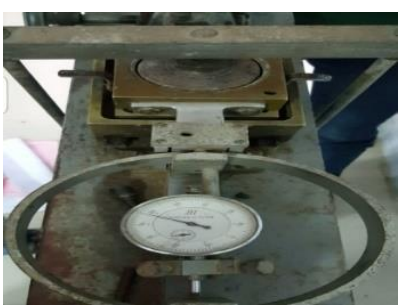

b)

Figure 2. Sample fabrication process and shear resistance test Sample for shear resistance; b) Shear resistance test

Experimental samples are made at different fly ash content from 35\%, 40\%, $45 \%$ to test the following parameters: Compressive strength, splitting tensile strength, determining the modulus of total mono-axial confined compression test, shear resistance, elastic modulus (Fig. 1 and Fig. 2).

\subsubsection{Results}

Test results of soil - fly ash mixture with the reinforcement content of 35\%, 40\%, 45\% fly ash are synthetized at Table 3, 4, 5 respectively.

Figure 1. Sample fabrication process and conducting the test a) Test sample of compressive strength; b) Test of total strain modulus

Table 3. Test result of soil - fly ash mixture with content of 35\%

\begin{tabular}{|c|c|c|c|c|c|c|c|}
\hline \multirow{2}{*}{ No } & \multirow{2}{*}{ Test criteria } & \multirow{2}{*}{ Test method } & \multirow{2}{*}{ Unit } & \multicolumn{4}{|c|}{ Test result } \\
\cline { 5 - 7 } & & & & $\mathbf{7}$ days & $\mathbf{1 4}$ days & $\mathbf{2 8}$ days & $\mathbf{5 6}$ days \\
\hline 1 & Compressive strength & {$[19]$} & $\mathrm{MPa}$ & 0.108 & 0.208 & 0.28 & 0.32 \\
\hline 2 & $\begin{array}{c}\text { Monoaxial } \\
\text { Confined compression }\end{array}$ & {$[20]$} & $\mathrm{MPa}$ & - & - & - & 1.33 \\
\hline 3 & Elastic modulus & {$[21]$} & $\mathrm{MPa}$ & - & - & - & 102 \\
\hline
\end{tabular}

Table 4. Test result of soil - fly ash mixture with content of $40 \%$

\begin{tabular}{|c|c|c|c|c|c|c|c|}
\hline \multirow{2}{*}{ No } & \multirow{2}{*}{ Test criteria } & \multirow{2}{*}{ Test method } & \multirow{2}{*}{ Unit } & \multicolumn{4}{|c|}{ Test result } \\
\cline { 5 - 7 } & & & & $\mathbf{7}$ days & $\mathbf{1 4}$ days & $\mathbf{2 8}$ days & $\mathbf{5 6}$ days \\
\hline 1 & Compressive strength & {$[19]$} & $\mathrm{MPa}$ & 0.114 & 0.219 & 0.29 & 0.33 \\
\hline 2 & $\begin{array}{c}\text { Monoaxial } \\
\text { Confined compression }\end{array}$ & {$[20]$} & $\mathrm{MPa}$ & - & - & - & 0.99 \\
\hline 3 & Elastic modulus & {$[21]$} & $\mathrm{MPa}$ & - & - & - & 124 \\
\hline
\end{tabular}

Table 5. Test result of soil - fly ash mixture with content of $45 \%$

\begin{tabular}{|c|c|c|c|c|c|c|c|}
\hline \multirow{2}{*}{ No } & \multirow{2}{*}{ Test criteria } & \multirow{2}{*}{ Test method } & \multirow{2}{*}{ Unit } & \multicolumn{4}{|c|}{ Test result } \\
\cline { 5 - 8 } & & & $\mathbf{7}$ days & $\mathbf{1 4}$ days & $\mathbf{2 8}$ days & $\mathbf{5 6}$ days \\
\hline 1 & Compressive strength & {$[19]$} & $\mathrm{MPa}$ & 0.12 & 0.23 & 0.31 & 0.35 \\
\hline 2 & $\begin{array}{c}\text { Monoaxial } \\
\text { Confined compression }\end{array}$ & {$[20]$} & $\mathrm{MPa}$ & - & - & - & 0.85 \\
\hline 3 & Elastic modulus & {$[21]$} & $\mathrm{MPa}$ & - & - & - & 140 \\
\hline
\end{tabular}

Based on the above test results, we can graph the relationship between the fly ash content in reinforcement and the sample strength growing over time as Fig. 3 . 


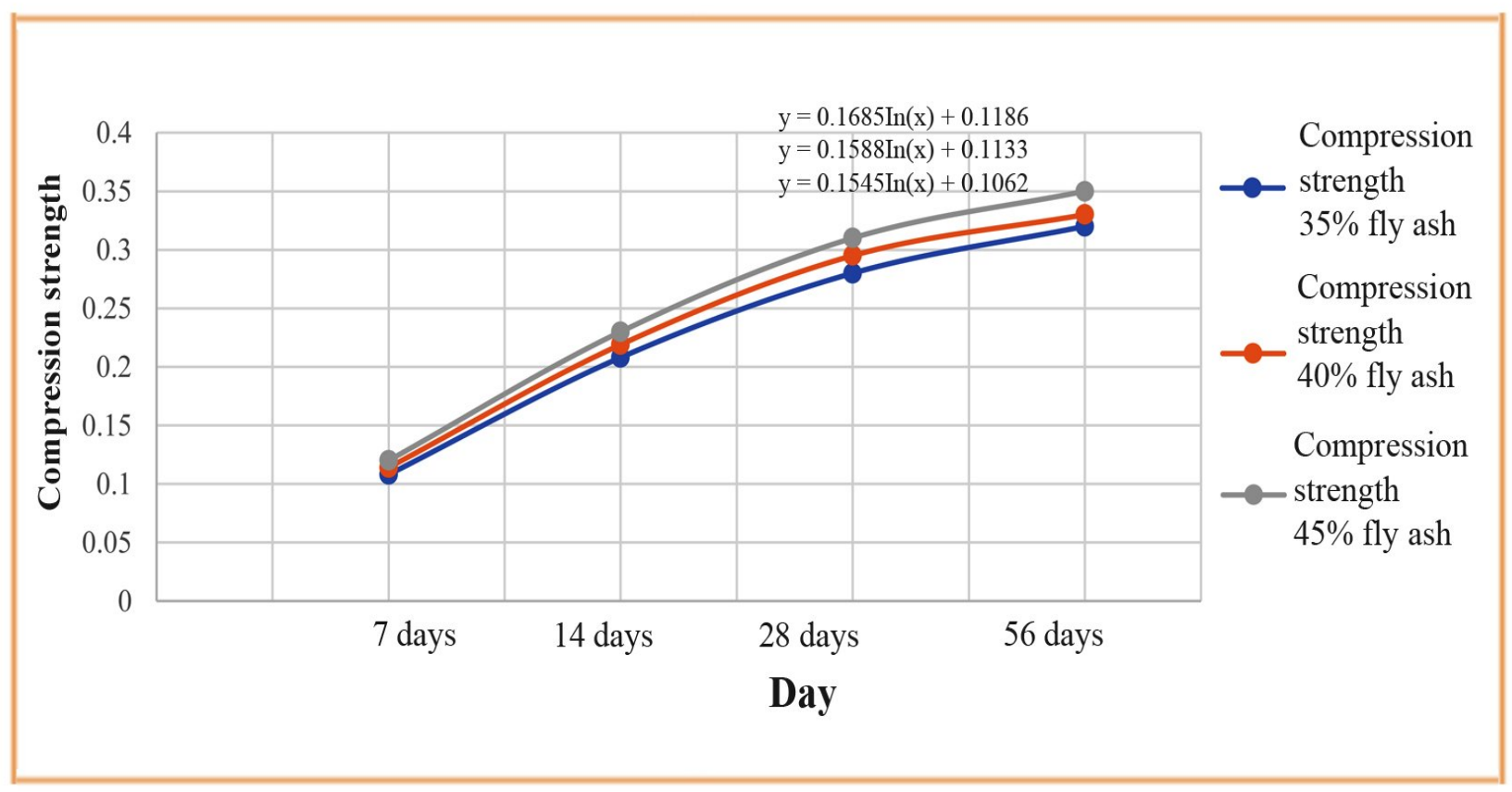

Figure 3. Relationship between fly ash content for reinforcement and sample compressive strength develops over time

\subsection{Numerical simulation on Plaxis V8.2}

\subsubsection{Calculation Cases}

The reasonable distance of piles according to TCVN $10304: 2014$ is from $(1.5 \div 6) \mathrm{D}$, normally from $(1 \div 3) \mathrm{D}$. The authors chose the distance between the piles as follows: 3.75D for $\mathrm{d} 400$ piles, 3D for $\mathrm{d} 500$ piles and 2.5D for $\mathrm{d} 600$ piles. The purpose of the study is to find the relationship between the reinforcement ratio with the stability and settlement of the construction; therefore, only changes resulted from pile diameter are recorded;

Researches of Khoi and Linh (2013) [9], Zygmunt Meyer and Piotr Cichocki (2020) [28] show that the diameter has a significant impact on the load capacity of the pile. The completely treated length pile is $8 \mathrm{~m}$, calculated based on the calculated settlement area, and fully treated depth of the soft ground.

Case 1: Change of pile diameter: D400, D500, D600.

Case 2: Change of fly ash content: $35 \%, 40 \%, 45 \%$;

\subsubsection{Results}

A. In case of D600-35\% fly ash piles, the distance between 2 piles is $1.5 \mathrm{~m}$

When reinforcing D600 - 35\% fly ash piles, the result obtained as Figs. 4-6. 


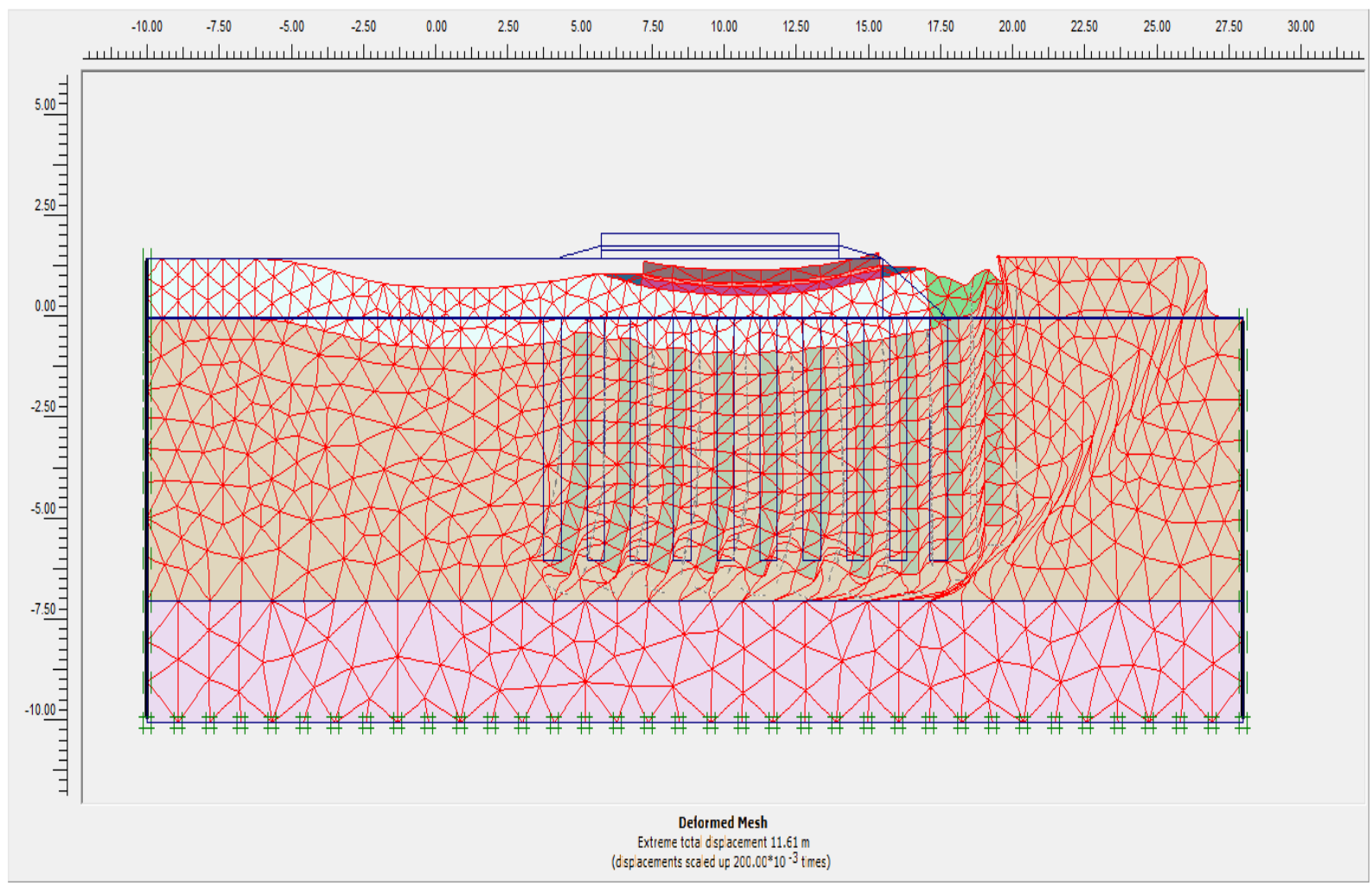

Figure 4. The displacement of the roadbed on soft ground when reinforcing D600 - 35\% fly ash piles (Maximum settlement of the road foundation S= $-0.245 \mathrm{~m}$ )

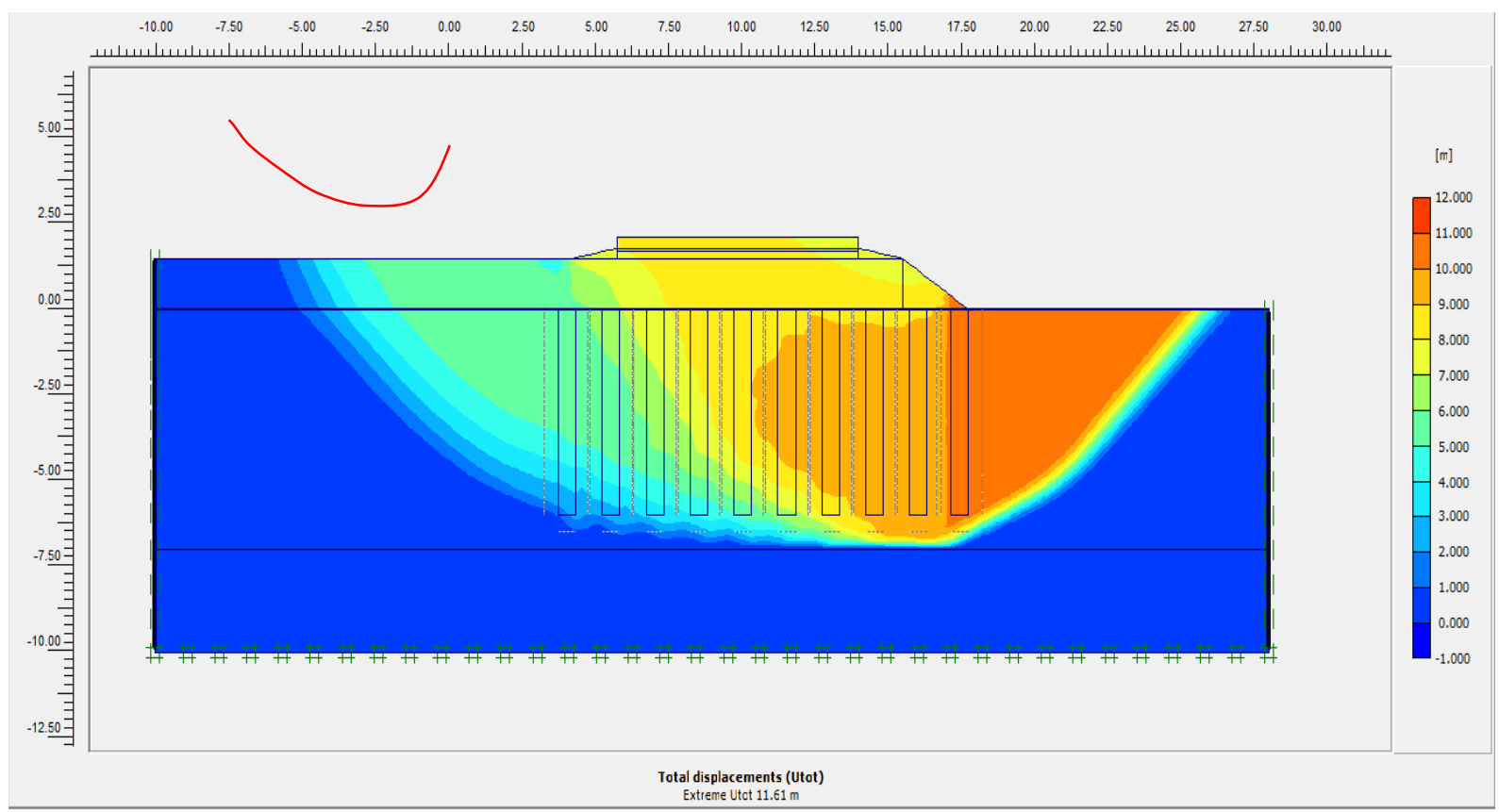

Figure 5. Location of dangerous slip surface of roadbed on soft ground when reinforcing D600 fly ash pile - 35\% fly ash 


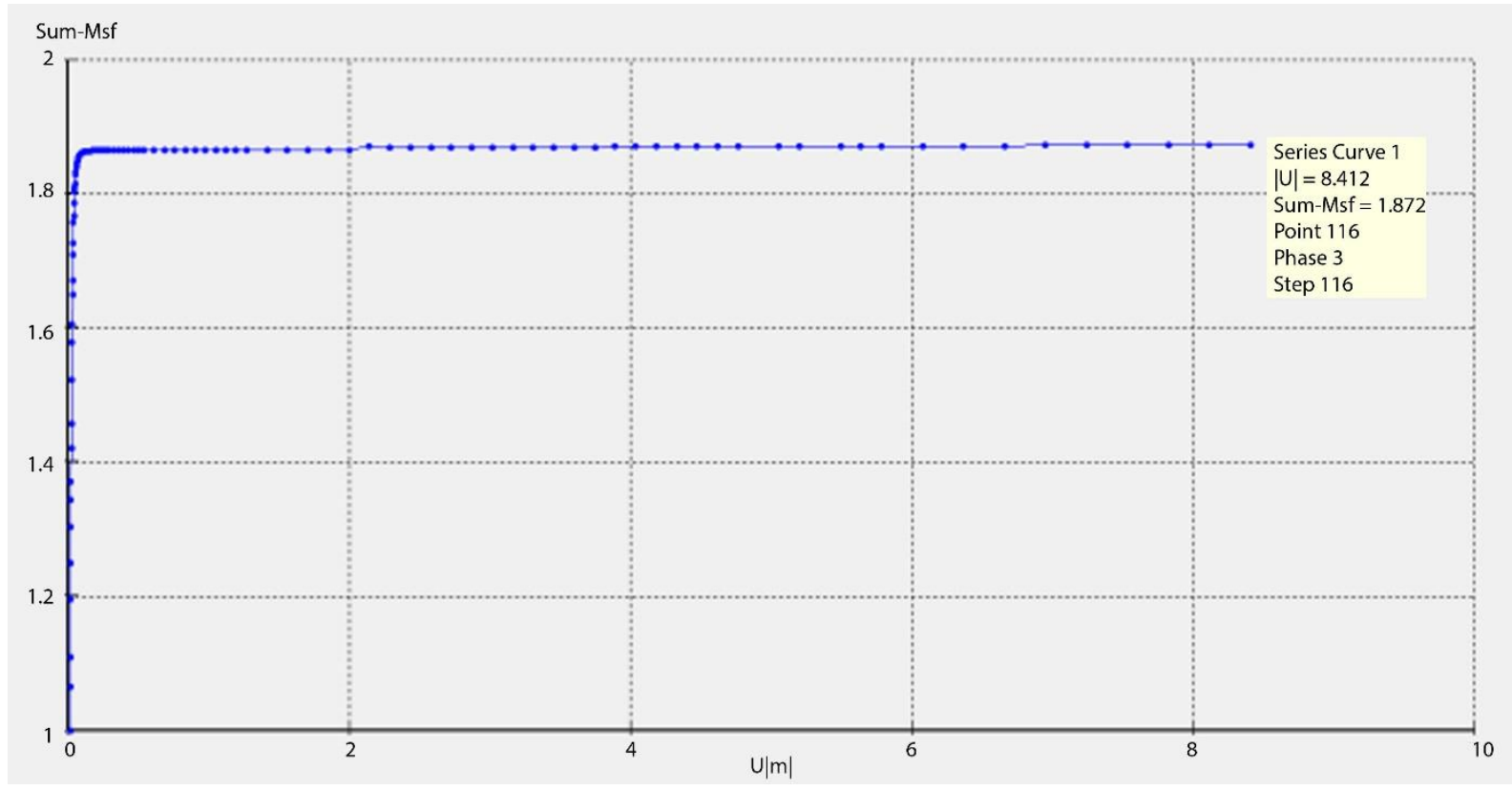

Figure 6. Stability coefficient against sliding of the roadbed on soft ground when reinforcing D600 -35\% fly ash piles $(\mathrm{K}=1.872)$

B. In case of D600-40\% fly ash piles, the distance between 2 piles is $1.5 \mathrm{~m}$

When reinforcing D600 - 40\% fly ash piles, the result obtained as Figs. 7-9.

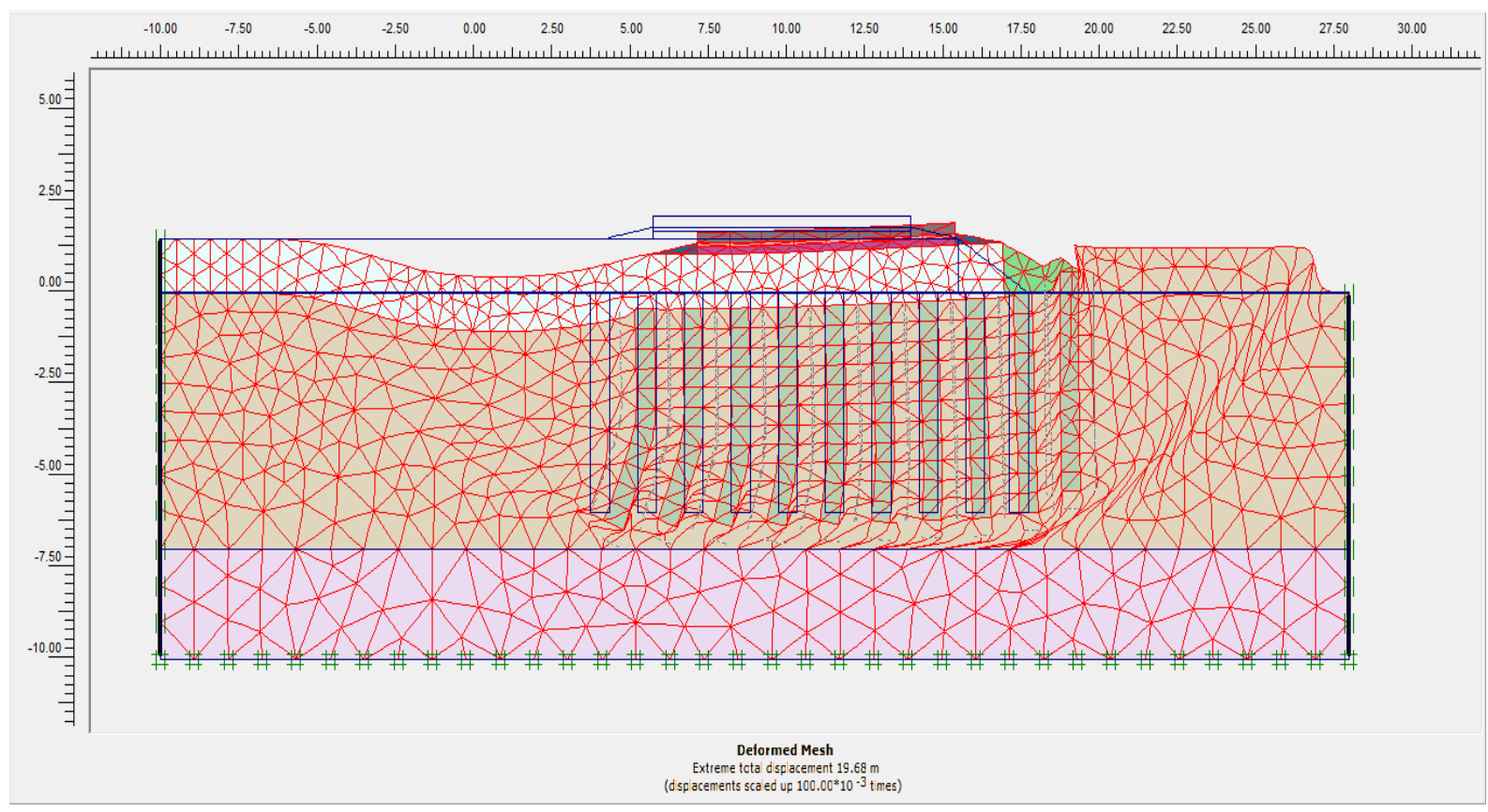

Figure 7. The displacement of the roadbed on soft ground when reinforcing D600 - 40\% fly ash piles (Maximum settlement of the road foundation S $=-0.172 \mathrm{~m})$ 


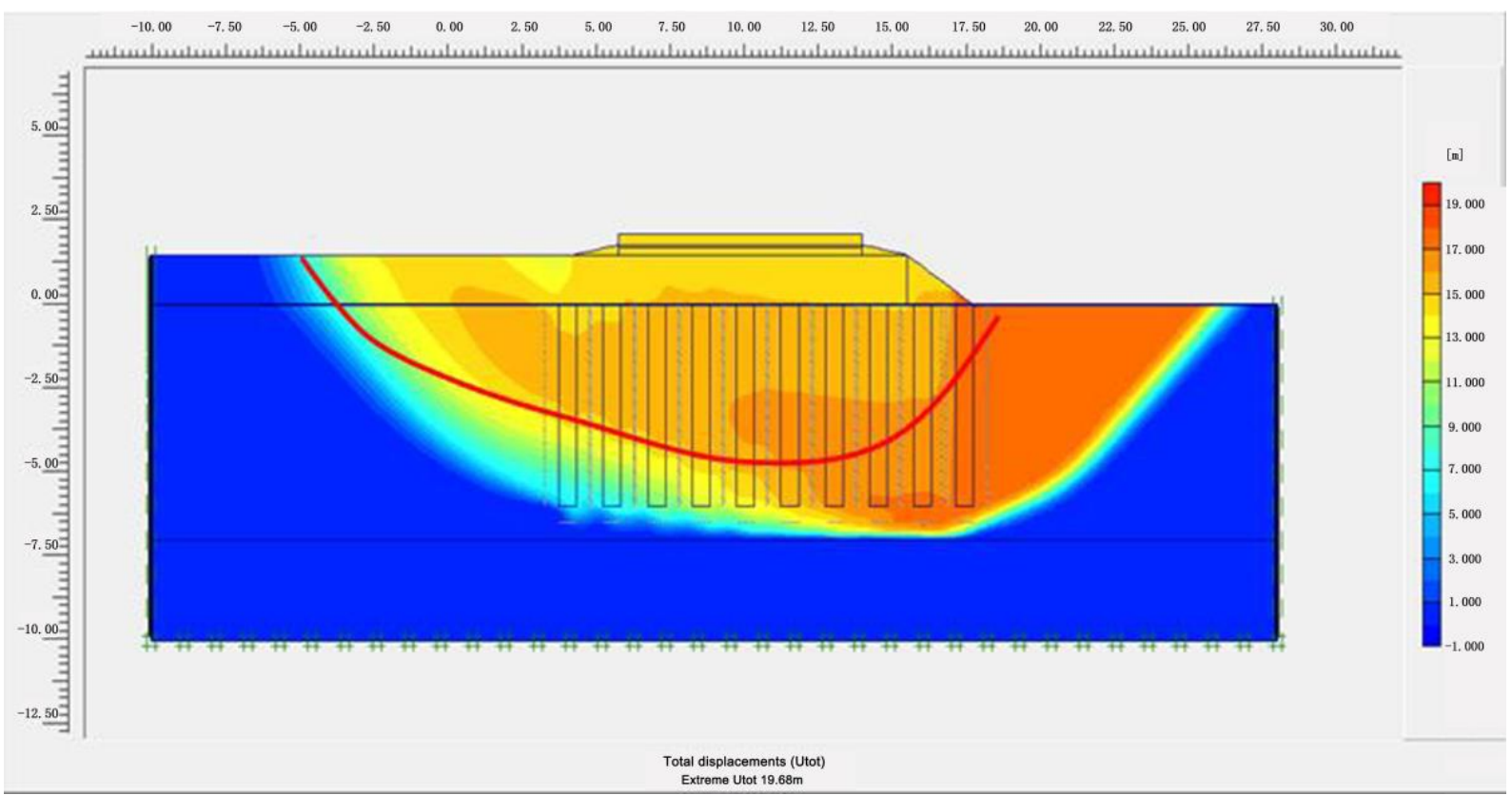

Figure 8. Location of dangerous slip surface of roadbed on soft ground when reinforcing D600 - 40\% fly ash pile

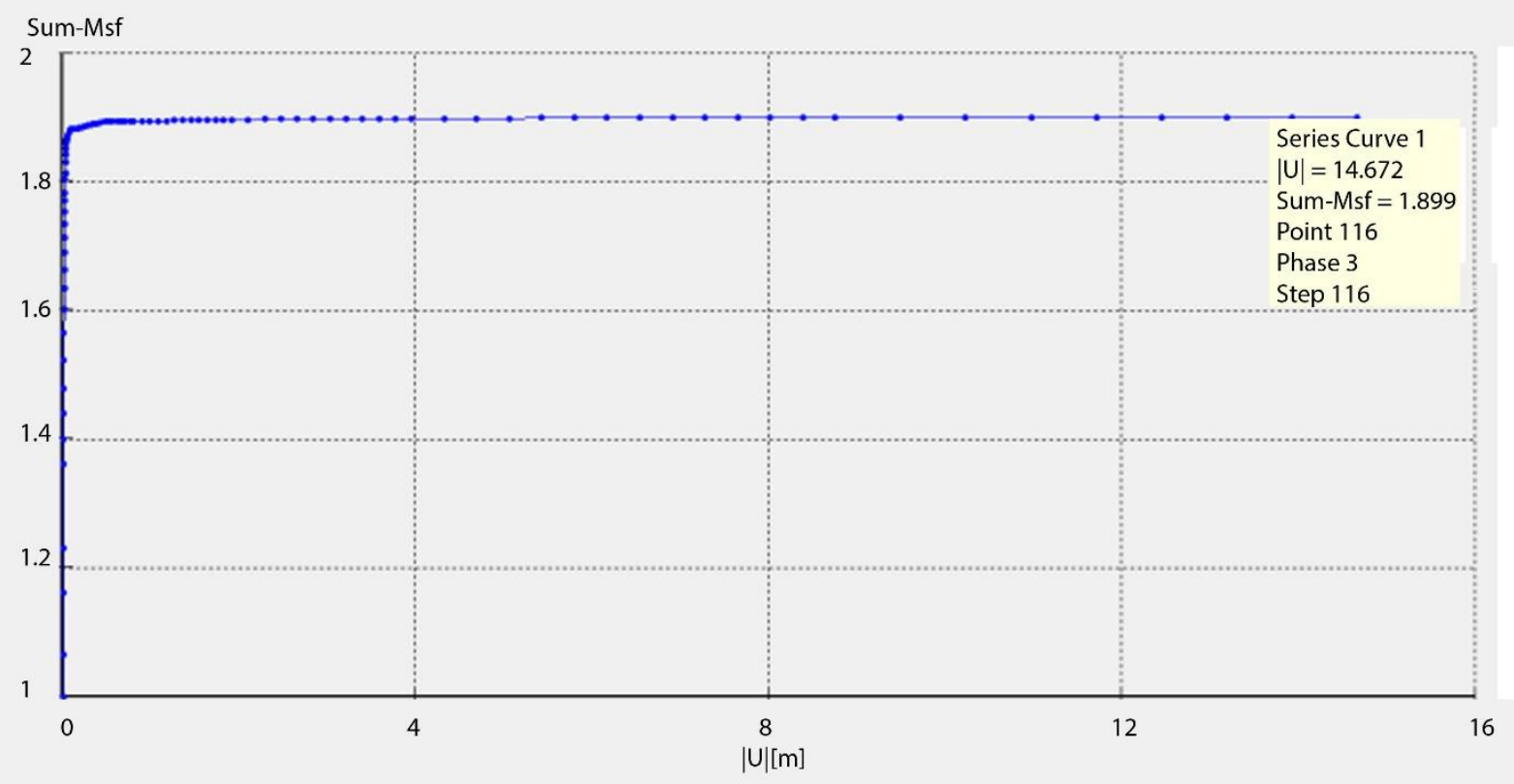

Figure 9. Stability coefficient against sliding of the roadbed on soft ground when reinforcing D600 - 40\% fly ash piles ( $\mathrm{K}=1.899)$

C. In case of D600-45\% fly ash piles, the distance between 2 piles is $1.5 \mathrm{~m}$

When reinforcing D600 - 45\% fly ash piles, the result obtained as Figs. 10-12. 


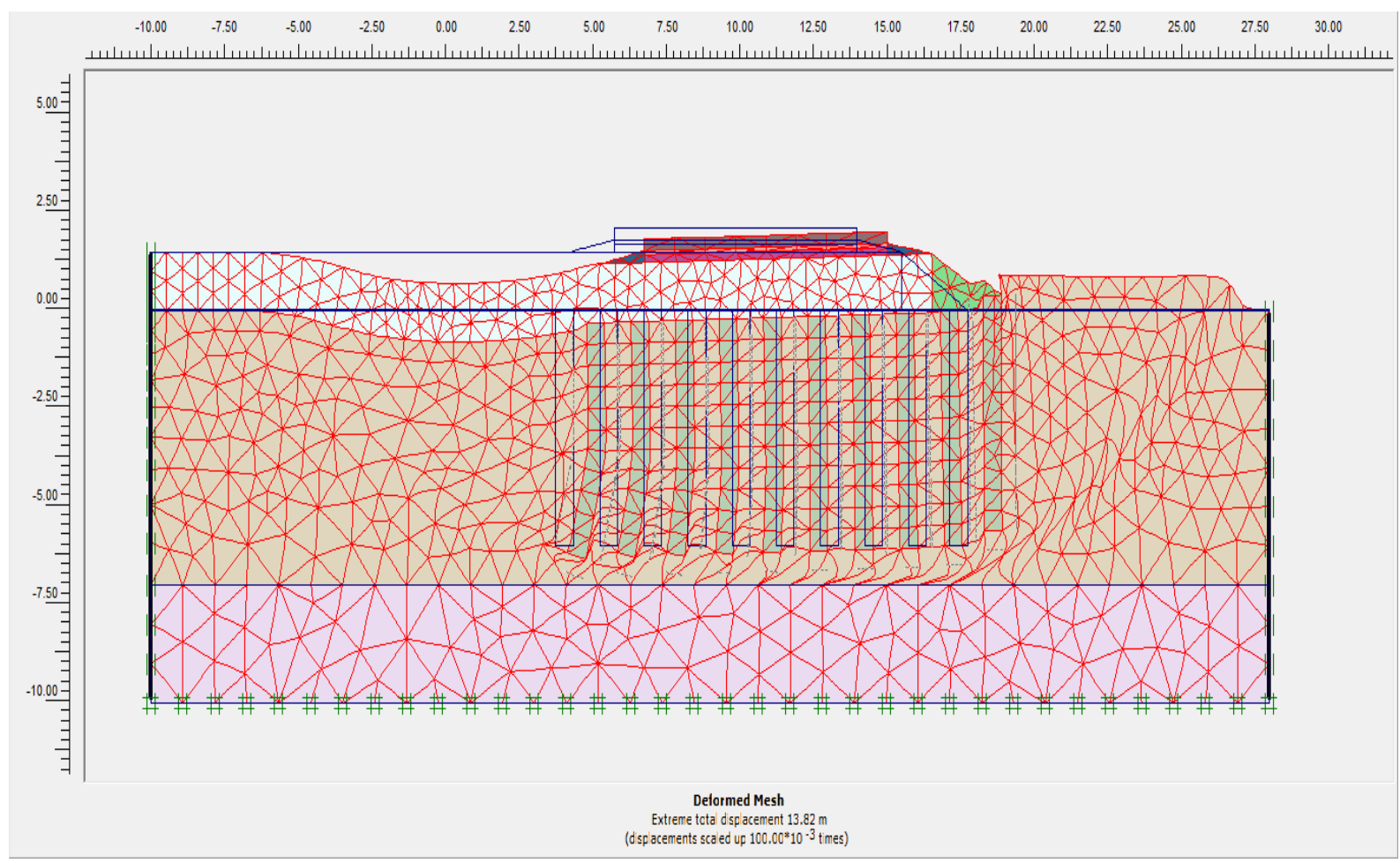

Figure 10. The displacement of the roadbed on soft ground when reinforcing D600 - 45\% fly ash piles (Maximum settlement of the road foundation $\mathrm{S}=$ $-0.170 \mathrm{~m}$ )

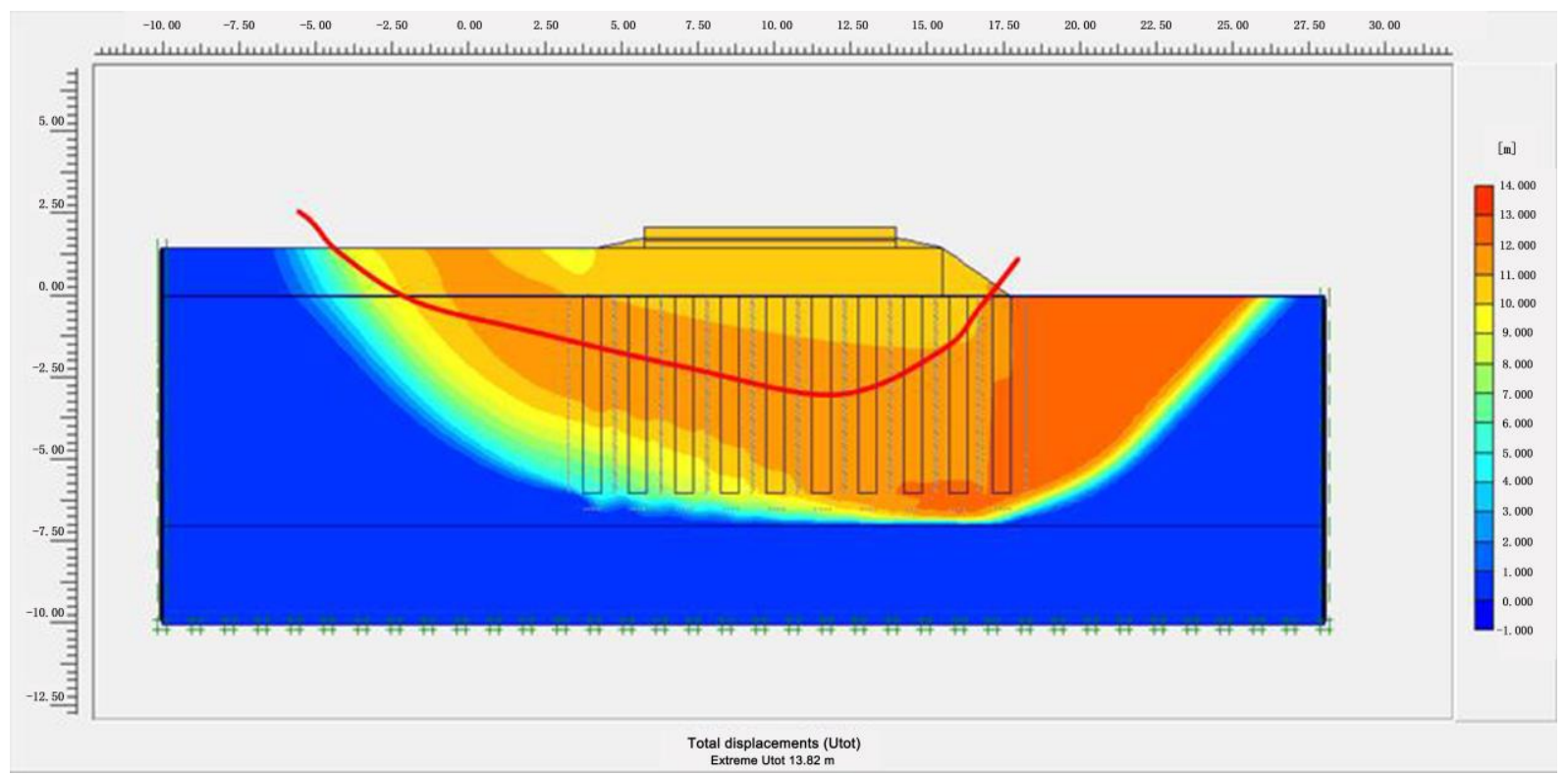

Figure 11. Location of dangerous slip surface of roadbed on soft ground when reinforcing D600 - $45 \%$ fly ash piles 


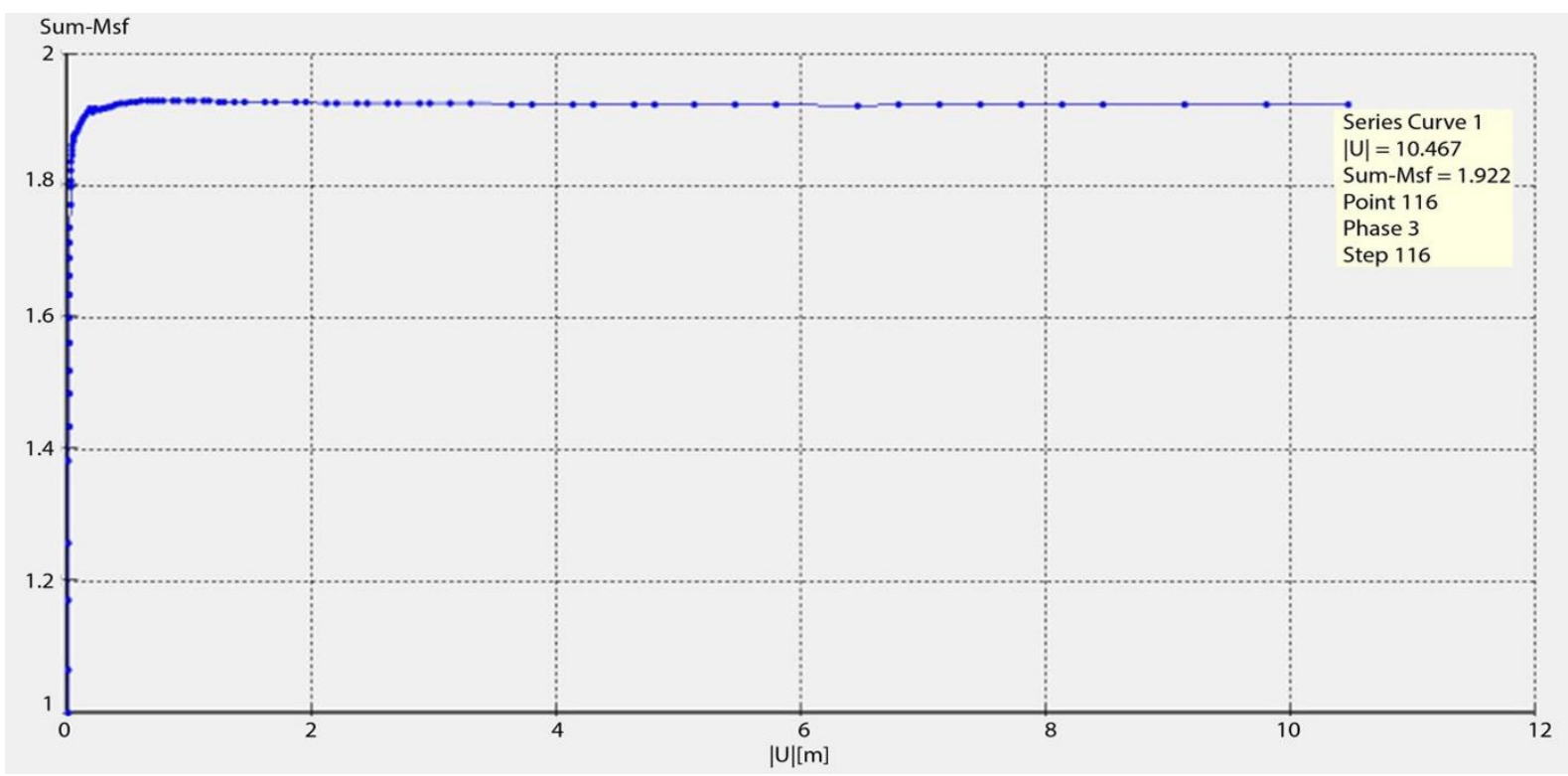

Figure 12. Stability coefficient against sliding of the roadbed on soft ground when reinforcing D600 - 45\% fly ash piles $(\mathrm{K}=1.922)$

\subsubsection{Discussion}

A. Stability coefficient

Stability coefficient according to calculations $[\mathrm{K}]=1.4$ is synthetized as table 6 .

Table 6. Result of stability coefficient

\begin{tabular}{|c|c|c|c|}
\hline & \multicolumn{3}{|c|}{ Stability coefficient } \\
\cline { 2 - 4 } & $35 \%$ fly ash & $40 \%$ fly ash & $45 \%$ fly ash \\
\hline D400 & 1.584 & 1.723 & 1.872 \\
\hline D500 & 1.666 & 1.836 & 1.899 \\
\hline D600 & 1.762 & 1.881 & 1.922 \\
\hline
\end{tabular}

The diagram of the relationship between the stability coefficient according to the pile diameter and the reinforced fly ash content is shown in Fig. 13.

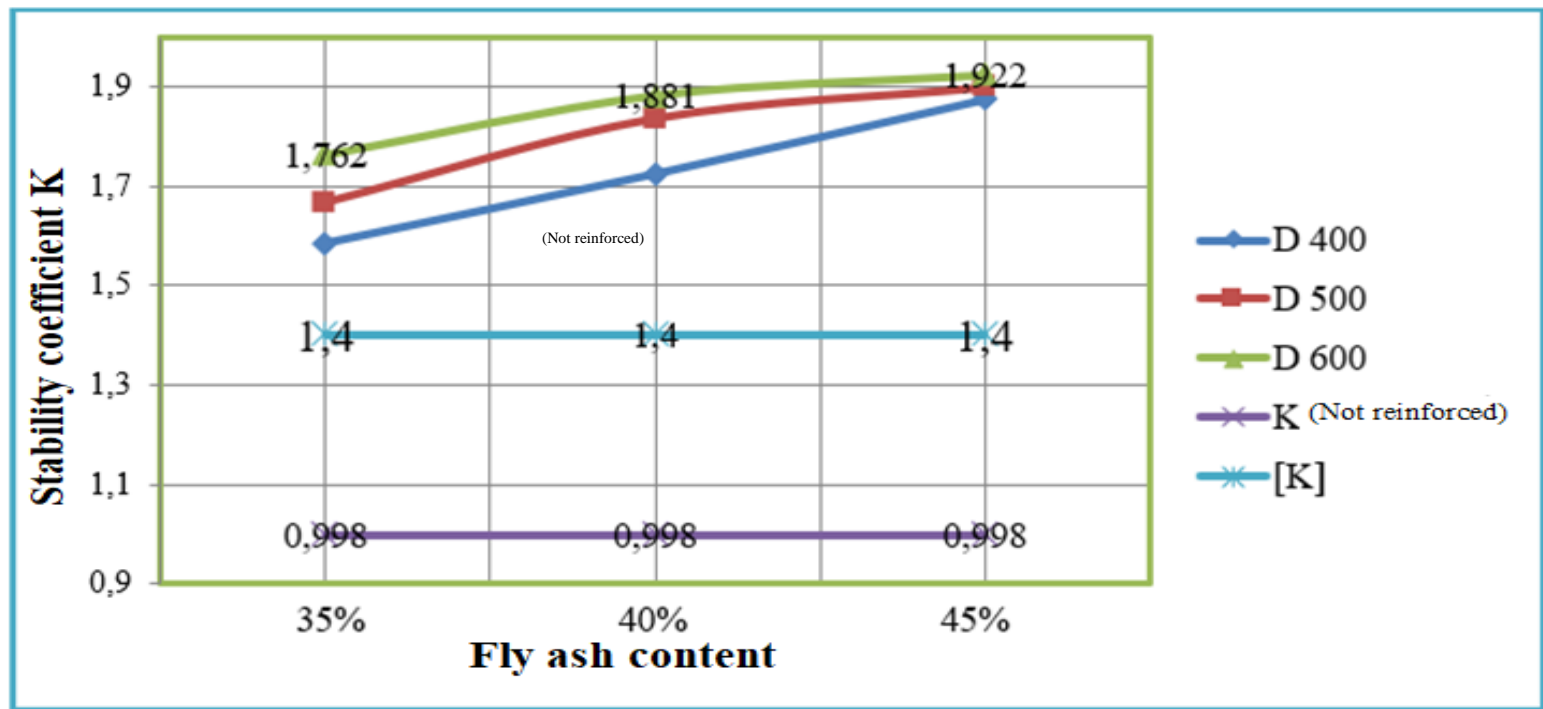

Figure 13. Diagram of relationship between stability coefficient and fly ash content

Through the chart of the relationship between the stability coefficient $\mathrm{K}$ with the pile diameter and fly ash content, it is shown that the larger the pile diameter is and the higher the fly ash content is, the higher the stability coefficient $\mathrm{K}$ is.

In terms of technical aspects, the author proposes to choose piles with diameter $\mathrm{D}=60 \mathrm{~cm}$, pile length $\mathrm{L}=8 \mathrm{~m}$ with fly ash content of $45 \%$ for the most optimal coefficient of K. 


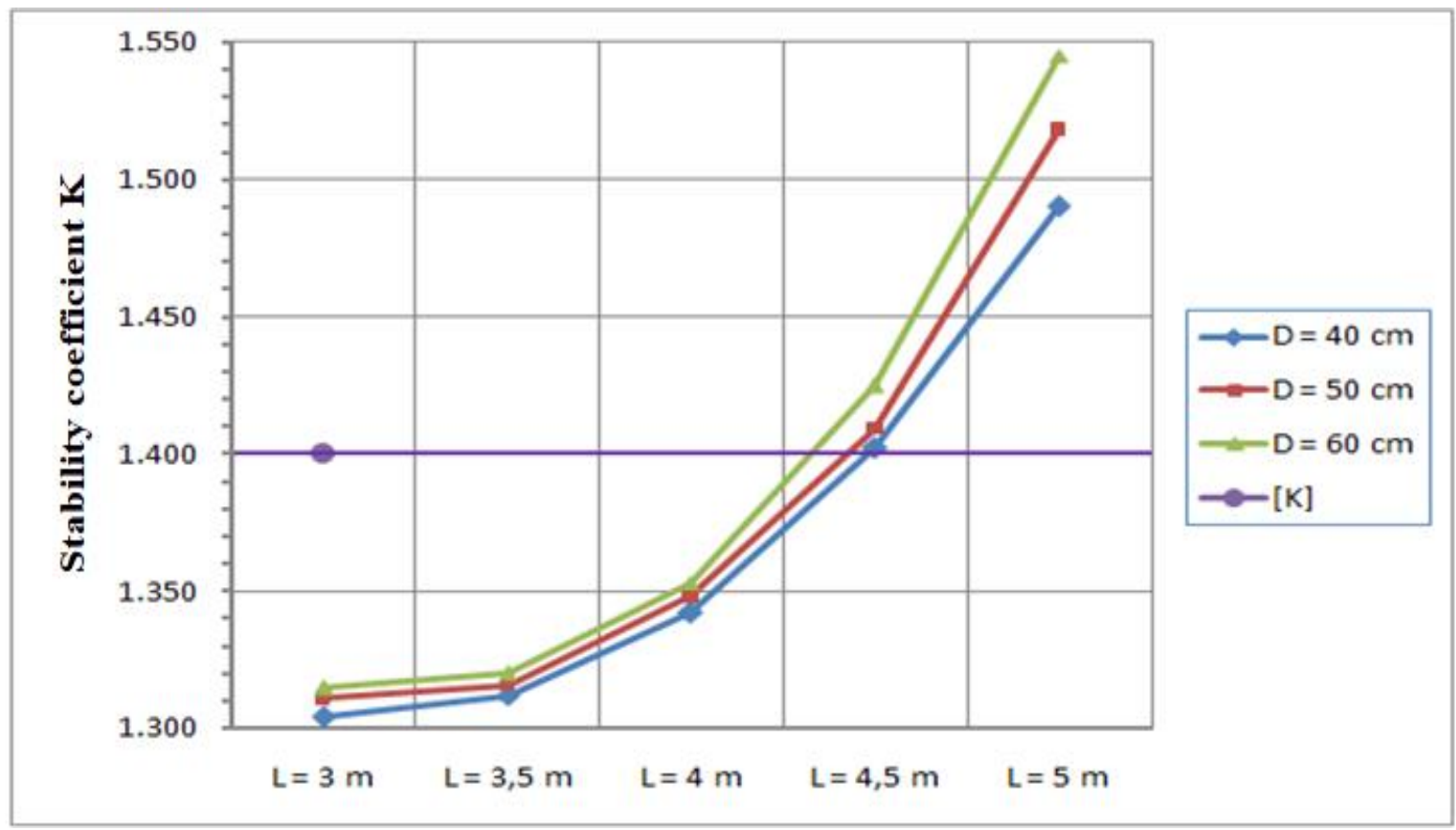

Figure 14. Diagram of relationship between stability coefficient $K$ and size of cement-soil pile

Comparing with the research results of [9] on stability coefficient K, this research shows that when using the fly ashsoil pile with the same diameter of D600 and the fly ash content is $45 \%$, the stability coefficient $\mathrm{K}$ is higher than that of a soil-cement pile (Fig. 14).

B. Roadbed settlement

Calculation results of the roadbed settlement are synthetized at Table 7.

Table 7. Calculation results of the roadbed settlement

\begin{tabular}{|c|c|c|c|}
\hline & \multicolumn{3}{|c|}{ Roadbed settlement (m) } \\
\cline { 2 - 4 } & $35 \%$ fly ash & $40 \%$ fly ash & $45 \%$ fly ash \\
\hline D400 & 0.362 & 0.311 & 0.252 \\
\hline D500 & 0.348 & 0.243 & 0.219 \\
\hline D600 & 0.245 & 0.172 & 0.170 \\
\hline
\end{tabular}

The diagram of relationship between settlement by pile diameter and fly ash content reinforced is illustrated in Fig. 15.

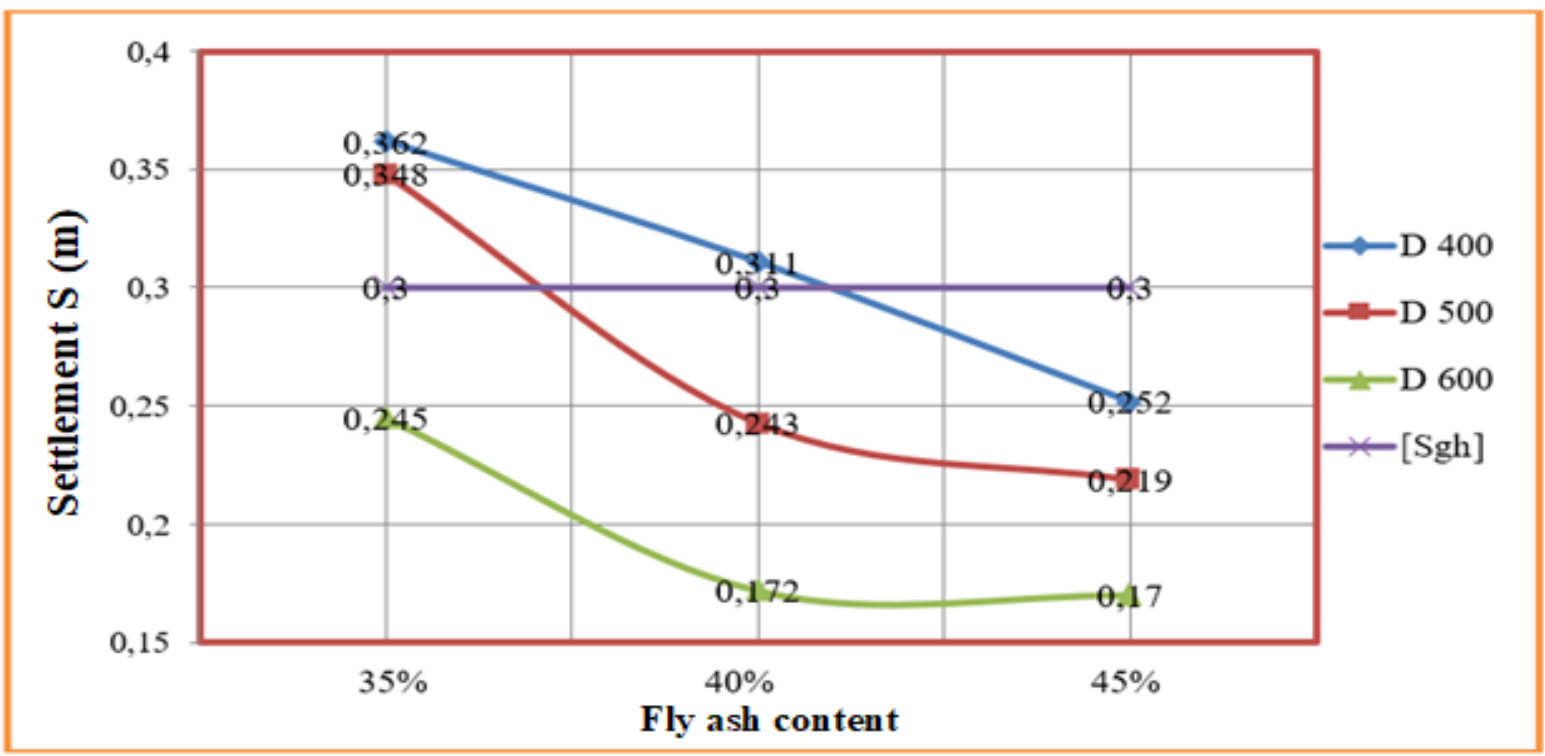

Figure 15. Diagram of relationship between pile settlement and reinforced fly ash content 
Through the chart of relationship between the settlement $\mathrm{S}$ with pile diameter and fly ash content, we notice that the larger the pile diameter is, and the higher the fly ash content is, the lower the settlement is.

For D400, D500 piles, when reinforced with fly ash content of $35 \%$, the settlement is not guaranteed compared with the permissible limit settlement, when the fly ash content increases to $40 \%, 45 \%$, the construction settlement is smaller than the permissible limit settlement. These results prove that the settlement of the building decreases gradually when we increase the pile diameter and fly ash content.

In terms of technical aspects, the author proposed to choose piles with diameter $\mathrm{D}=60 \mathrm{~cm}$, pile length $\mathrm{L}=8 \mathrm{~m}$ with fly ash content of $45 \%$, resulting in the most optimal settlement $\mathrm{S}$.

\section{Conclusions}

Mechanical and physical properties, material characteristics used in the topic are taken directly from the experiment.

When designing the project without reinforcement of the fly ash -soil piles, the displacement at the bottom of the roadbed is too large, thus, it is clear that the roadbed needs treatment. The author modeled the calculation diagram of soft ground reinforcement under Mau Than roadbed with the assuming pile diameter $\mathrm{D}=40 \mathrm{~cm} ; 50 \mathrm{~cm} ; 60 \mathrm{~cm}$ corresponding to the content of fly ash $35 \%, 40 \%, 45 \%$, the pile length $\mathrm{L}=8 \mathrm{~m}$ to handle all the soft soil layers.

Thereby, it is able to analyze the performance of fly ash-soil piles at different diameters and fly ash content. With the pile length $\mathrm{L}=8 \mathrm{~m}$, pile diameter $\mathrm{D}=60 \mathrm{~cm}$ corresponding to the fly ash content of $45 \%$, the stability coefficient is $\mathrm{K}=1.992$ which is greater than the allowable stability coefficient $[\mathrm{K}]=1.4$. The largest settlement strain in this case $\mathrm{S}=0.17 \mathrm{~m}$ ensures allowable settlement deformation of the ground $[\mathrm{S}]=0.3 \mathrm{~m}$.

Through the conversion of stress, displacement, deformation values and so on from the reduced model to the actual model, design and construction consultants and operation managers can use this model as a basis to offer solutions to ensure the construction stability during its operation duration.

\section{REFERENCES}

[1] An, C.N. Foundation, Ho Chi Minh National University Publisher, 2002.

[2] Balo, F., Yucel, H.L., Ucar, A. Determination of the thermal and mechanical properties for materials containing epoxidised palm oil, clay and fly ash. Int. J. Sustain. Eng. 3, 47-57, 2010
[3] Bich, N.N. Soft soil improvement methods in construction, Construction Publisher, Ha Noi, Viet Nam, 2010.

[4] D.T. Bergado, J.C. Chai, M.C. Alfaro, A.S. Balasubramaniam. New technical methods to improve soft ground in construction, Education Publisher, Ha Noi, Viet Nam, 1996.

[5] Cui, J.H. Research on Stability of Subgrade Soil Modified by Oil Shale Waste Residue and Fly Ash. Master's Thesis, Jilin University, Changchun, China, May 2018.

[6] Davidovits, J., M. Davidovics. Geopolymer room temperature ceramic matrix for composites", Ceramic Engineering Science Proc. 9, pp. 835-842, 1988.

[7] Davidovits. Properties of Geopolymer Cements, The proceeding First International Conference on Alkalie Cements and concretes- pp $131-139,1994$.

[8] Davidovits, J. Geopolymer Chemistry and Application. 2nd edn, Institut Geopolymere - Saint- Quentin, France, 2008.

[9] Le Van Khoi, Chau Truong Linh (2013). Study on application of embankment reinforced soil-cement piles combined with traffic roads of Kien Giang river, Quang Binh province. Transportation Journal, No.12, pp.35-41, 2013

[10] Kuan-Yeow Show, Joo-Hwa Tay; and Anthony T. C. Goh. Reuse of Incinerator Fly Ash in Soft Soil Stabilization, Journal of Materials in Civil Engineering, Volume 15 Issue 4 - August 2003.

[11] Lijun Wu. Performance of Geosynthetic-Reinforced and Cement-Fly Ash-Gravel Pile-Supported Embankments over Completely Decomposed Granite Soil: A Case Study. Advance in Material Science and Engineering, Volume 18, 11 pages, 2018.

[12] Lijun Wu, Guanlu Jiang, Nengpan Ju. Behavior and Numerical Evaluation of Cement-Fly Ash-Gravel Pile-Supported Embankments over Completely Decomposed Granite Soils. International Journal of Geomechanics, Volume 19 Issue 6, 2019.

[13] $\mathrm{Na} \mathrm{Li} \mathrm{et} \mathrm{al.} \mathrm{Compression} \mathrm{Characteristics} \mathrm{and} \mathrm{Microscopic}$ Mechanism of Coastal Soil Modified with Cement and Fly Ash. Materials, Volume 12, 18 pages, 2019.

[14] Thuy N.B.T. Study on using waste Fly Ash in subgrade construction. Master's thesis, Hochiminh City University of Transport, 2020.

[15] Wang, D.X.; Zentar, R.; Abriak, N.E. Durability and swelling of solidified/stabilized dredged marine soils with Class-F fly ash, cement, and lime. J. Mater. Civ. Eng. 30, 04018013, 2018.

[16] Wei H.B. et al. Experimental research on resilient modulus of silty clay modified by oil shale ash and fly ash after freeze-thaw cycles. Applied Sciences 2018, 8, 1298. 19 pages, 2018.

[17] Wei, H.B.; Zhang, Y.P.; Cui, J.H.; Han, L.L.; Li, Z.Q. Engineering and environmental evaluation of silty clay modified by waste fly ash and oil shale ash as a road subgrade material. Constr. Build. Mater. 2018.

[18] Xiao, H.W.; Wang, W.; Goh, S.H. Effectiveness study for fly ash cement improved marine clay. Constr. Build. Mater. 
157, pp. 1053-1064, 2017.

[19] Vietnamese Standard TCVN 9403-2012, Stabilization of soft soil- The soil cement column method, 2012.

[20] Vietnamese Standard TCVN 4200-2012, Soils - Laboratory methods for determination of compressibility, 2012.

[21] Vietnamese Standard TCVN 9483-2013, Standard test method in the laboratory for resilient modulus of nonorgannic adhesive substance stabilizied aggregate material, 2013.

[22] Vietnamese Standard TCVN 7204-2013, Portland cement clinker, 2013.

[23] Vietnamese Stanrdard TCVN 4030:2003: Cement - Test method for determination of fineness, 2003.

[24] Vietnamese Stanrdard TCVN 8262:2009: Fly ash - Methods of chemical analysis, 2003.

[25] Vietnamese Stanrdard TCVN 141:2008: Portland cement Methods of chemical analysis, 2012.

[26] Martin Tazky, Rudolf Hela, "High-Performance Concretes Intended for Deep Foundations of Constructions," Civil Engineering and Architecture, Vol. 8, No. 2, pp. 46 - 54, 2020. DOI: $10.13189 /$ cea.2020.080202.

[27] Mochamad Solikin, Alfian Nur Zaini, Budi Setiawan, Ali Asroni, "Flexural Strength Analysis of Styrofoam Concrete Hollow Panel Walls Incorporated with High Volume Fly Ash," Civil Engineering and Architecture, Vol. 8, No. 3, pp. 320 - 325, 2020. DOI: 10.13189/cea.2020.080316.

[28] Zygmunt Meyer, Piotr Cichocki, "Analysis of Combined Pile Raft Foundations Based on a Static Load Test," Civil Engineering and Architecture, Vol. 8, No. 2, pp. 101 - 112, 2020. DOI: $10.13189 /$ cea.2020.080208. 